\title{
Locomotor Activity of Terrestrial Predators and Its Consequences:
}

\author{
Jacek GOSZCZYNSKI
}

\begin{abstract}
Goszczyński J., 1986: Locomotor activity of terrestrial predators and its consequences. Acta theriol., 31, 6: 79-95 [With 4 Tables \& 1 Fig.] The relations between body mass $(M)$ and daily movement distance $(D M D)$, daily food consumption $(D F C)$ and home range size $(H R)$ were examined in three families of Carnivora. The relative locomotion costs of these animals and intensity of penetration of their home ranges were estimated, and it was shown that during the course of 24 hours Mustelidae cover greater distances than Canidae and Felidae possessing the same body mass. In the case of the largest representatives of the families examined relative locomotion costs may be as much as $30-40 \%$ of their DFC. In all the families studied intensity of movement over the home range decreases together with increase in body mass. The energetic advantages of movement do not depend on body mass in the case of Mustelidae, whereas Canidae and Felidae increase advantage with increase in body mass.

[Warsaw Agricultural University, Faculty of Forestry, Department of Game Management, Rakowiecka 26/30, 02-528 Warsaw, Poland]
\end{abstract}

\section{INTRODUCTION}

Increased interest has been manifested in recent years in problems: of utilization of space by animals, particularly the relations between body mass and home range size (McNab, 1963; Schoener, 1968; Harestad \& Bunnel, 1979; Gittleman \& Harvey, 1982). Little attention has been paid to comparative analysis of daily movements, the successive records of which make up the animal's home range. Garland (1983) was the first to point out the relation between the animal's body mass and its daily movement distance, describing from this aspect 76 species of mammals. His paper also contains a large number of important findings on the ecological cost of mammals' transport. Although he also took predators into consideration, the number of their species (13) discussed is too small to make it possible to arrive at any general conclusions.

In the present study the problem of locomotion has been dealt with in greater detail, but is limited to the order of Carnivora only. It appeared desirable to analyze the activity of predators for the following reasons: (1) The different families of Carnivora differ as to hunting strategy and therefore analysis of distance of movement could supply infor- 
mation as to the effectiveness of hunting and locomotion costs of animals belonging to these families, (2) a knowledge of the relation between body mass and daily movement distance would make it possible to grasp differences in intensity of movement over a given area by both large and small animals, the degree of overlapping of home ranges and possibilities of variations in activity.

\section{METHODS}

Data in literature were collected on daily movement distance ( $D M D)$, daily food consumption $(D F C)$ and home range $(H R)$ of various European, Asiatic (from Soviet Union territory) and North American predatory species (Table 1). In one

\section{Table 1}

Relation between body mass (M) and: daily movement distance (DMD), home range size (HR) and daily food consumption (DFC). Numbers in brackets indicate successive papers in references.

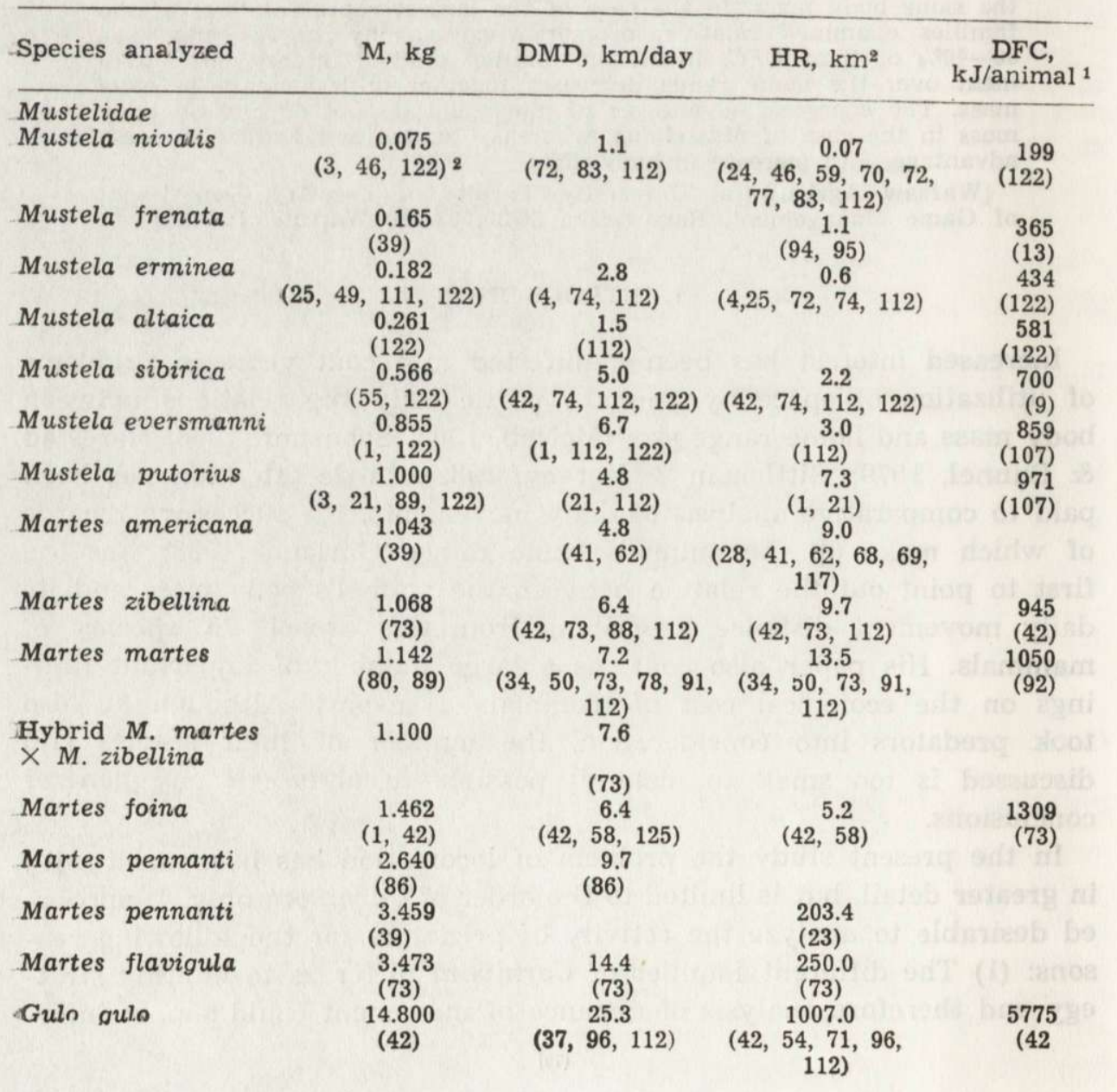




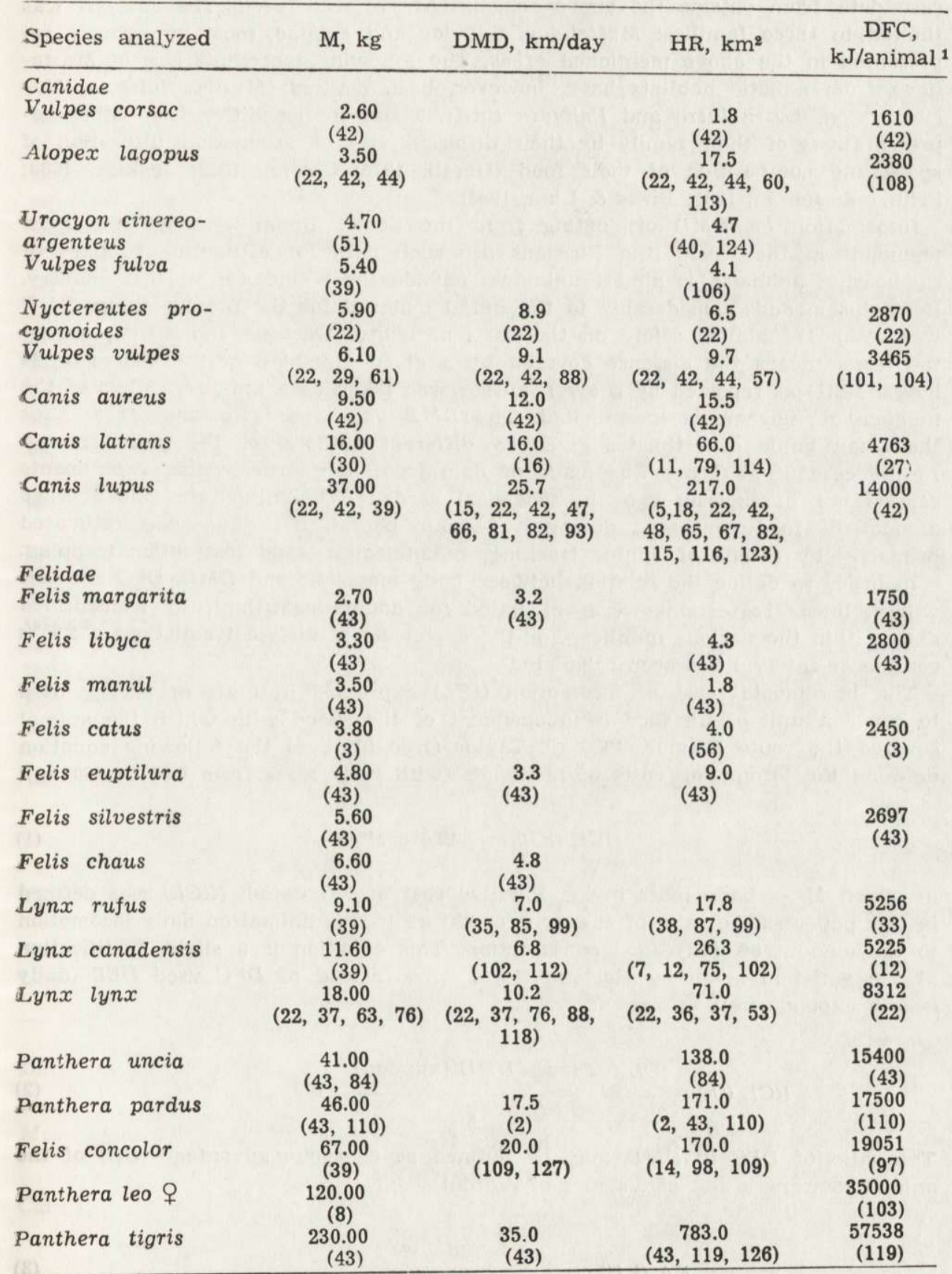

1 In cases when DFC has been given in grams of meat consumed, this value has been multiplied by 7 (mean energetic value of $1 \mathrm{~g}$ of the prey's tissue in $\mathrm{kJ}$, after Ryszkowski 1982).

z Use has also been made of the author's own estimates (Goszczyński, unpublished).

6 - Acta Theriologica 
case data from outside the above regions (Africa) were used. The analysis was limited to three families: Mustelidae, Canidae and Felidae, most numerously represented in the above mentioned areas. The following representatives of Mustelidae from aquatic habitats have, however, been omitted: Mustela lutreola, Mustela vison, Lutra lutra and Enhydra lutris. These species differ from other representatives of their family by their different way of locomotion, utilization of space and composition of their food (Gerell, 1970; Chanin, 1972; Jenkins, 1980; Erlinge \& Jensen, 1981; Birks \& Linn, 1982).

Information on $D M D$ originating from the Soviet Union, although the most abundant in the world (the Russians use such data for estimating supplies of fur-bearing animals), is almost unknown outside the boundaries of that country. Its inclusion adds considerably to the initial material for the present study. $D M D$ was estimated almost solely on the basis of winter tracking and as implied by the term, means the distance covered by a given animal over the course of 24 hours. DMD as reported by a given author was taken as a unit, regardless of the number of movements investigated. The $D M D$ value used for analysis is thus the mean value of estimates given by different authors for the given species. In the case of $D F C$ use was made of data from long-term feeding experiments carried out in enclosures or in zoological gardens. DFC illustrates the average amount of food consumed during a 24-hour period. $H R$ value was estimated primarily by means of winter tracking, radiotelemetry and less often, trapping.

In order to define the relation between body mass $(M)$ and $D M D, D F C$ and $H R$ values, linear regressions were calculated for double-logarithmically transformed data within the various families. For the exponents of different equations a $\pm 95 \%$ confidence interval has been calculated.

The incremental cost of locomotion (ICL) expressed in units of energy used to cover a unit of distance is independent of the speed with which the animal covered the route (Taylor, 1980 a). Taylor $(1980 \mathrm{~b})$ gives the following equation defining the locomotion costs of mammals (with body mass from 0.01 to $260 \mathrm{~kg}$ ):

$$
\operatorname{ICL}(\mathrm{kJ} / \mathrm{km})=10.678 \mathrm{M}^{0.70}
$$

in which $M$ - body mass in kg. Relative cost of locomotion ( $R C L)$ was defined in this paper as the ratio of energy expenditure by the animal on daily locomotion to the amount of daily food consumption. This equation is a slight modification of the equation given by Garland (1983), who instead of $D F C$ used $D E E$ (daily energy expenditure):

$$
R C L(\%)=\frac{I C L}{(\mathrm{~kJ} / \mathrm{km}) \cdot D M D(\mathrm{~km} / \text { day })} \cdot 100
$$

The ratio of $D F C$ to $D M D$ may be defined as energetic advantage $(E A)$ of the animal covering a unit of distance of its route:

$$
E A(k J / k m)=\frac{D F C(k J / d a y)}{D M D(k m / d a y)}
$$

On the other hand the ratio of $D M D$ to $H R$ was taken as a measure of intensity of movement (penetration) over a unit of home range (IP): 


$$
\text { IP }\left(\mathrm{km} / \mathrm{km}^{2} \text { day }\right)=\frac{D M D(k m / d a y)}{H R\left(\mathrm{~km}^{2}\right)}
$$

IP is therefore expressed in $\mathrm{km}$ of route covered by an animal within $1 \mathrm{~km}^{2}$ of $H R$.

$E A$ and IP for different families of Carnivora may be calculated directly by relatir.g the appropriate values $D M D, H R$ and $D F C$ characteristic of the given species to equations (3) and (4). This results in calculating regression $E A$ and $I P$ to $M$ within the given family. As this method requires the full set of parameters $(M, D M D, H R$ and $D F C$ ) for each species this greatly reduces sample size. Another way consists in defining the relation between $M$ and other parameters: $D M D, H R$ and $D F C$, within the given predator families and relating the equations obtained to equations (3) and (4). In this second case, although we have a greater amount of data, such procedure makes it necessary to accept the assumption that variances for the different variables round regression lines are independent.

Both these ways of calculating EA and IP have been given parallel presentation in this paper.

List of abbreviations used:

$M \quad$ - body mass (kg)

$D M D$ - daily movement distance $(\mathrm{km} /$ day)

$D F C$ - daily food consumption (kJ/day)

$H R$ - home range $\left(\mathrm{km}^{2}\right)$

$R C L$ - relative cost of locomotion $(\%)$

$E A$ - energetic advantage of locomotion $(\mathrm{kJ} / \mathrm{km})$

IP - intensity of penetration of $H R\left(\mathrm{~km} / \mathrm{km}^{2}\right)$.

\section{DAILY MOVEMENT DISTANCE, RELATIVE COST OF LOCOMOTION AND ENERGETIC ADVANTAGE OF LOCOMOTION}

In the regressions calculated for different families, describing the relation of $D M D$ to $M$, the exponent was approximately 0.60 (Table 2).

Table 2

Least squares linear regression of $\log _{1 n}$ transformed $\mathrm{DMD}, D F C$ and $H R$ versus body mass (data from Table 1).

\begin{tabular}{lccccr}
\hline \multirow{2}{*}{ Data set } & \multicolumn{4}{c}{$\begin{array}{c}\text { Linear regression estimate of } D M D, \\
D F C \text { and } H R=a(\mathrm{mass})^{b}\end{array}$} \\
\cline { 3 - 6 } & & $a$ & $b \pm 95 \%$ C.I. & $r^{\mathbf{2}}$ & $n$ \\
\hline Mustelidae & $D M D$ & 5.758 & $0.60 \pm 0.11$ & 0.92 & 14 \\
& $D F C$ & 1037 & $0.60 \pm 0.06$ & 0.98 & 11 \\
& $H R$ & 9.381 & $1.79 \pm 0.33$ & 0.93 & 13 \\
Canidae & $D M D$ & 3.227 & $0.58 \pm 0.02$ & 0.99 & 5 \\
& $D F C$ & 835 & $0.73 \pm 0.24$ & 0.95 & 6 \\
& $H R$ & 0.500 & $1.65 \pm 0.69$ & 0.82 & 9 \\
Felidae & $H R 1$ & 0.247 & $1.90 \pm 0.29$ & 0.99 & 8 \\
& $D M D$ & 1.693 & $0.58 \pm 0.08$ & 0.98 & 9 \\
& $D F C$ & 890 & $0.76 \pm 0.06$ & 0.99 & 12 \\
& $H R$ & 0.810 & $1.34 \pm 0.22$ & 0.96 & 11 \\
\hline
\end{tabular}

1 Excluding Alopex. 
Analysis of the covariance shows that regressions for the three families under consideration differ from each other and it is therefore impossible in this case to apply one equation with a common slope $b \quad(t=55.4$, $p<0.001)$. Mustelidae thus move over greater distances than Canidae and Felidae with the same body mass (Fig. 1).

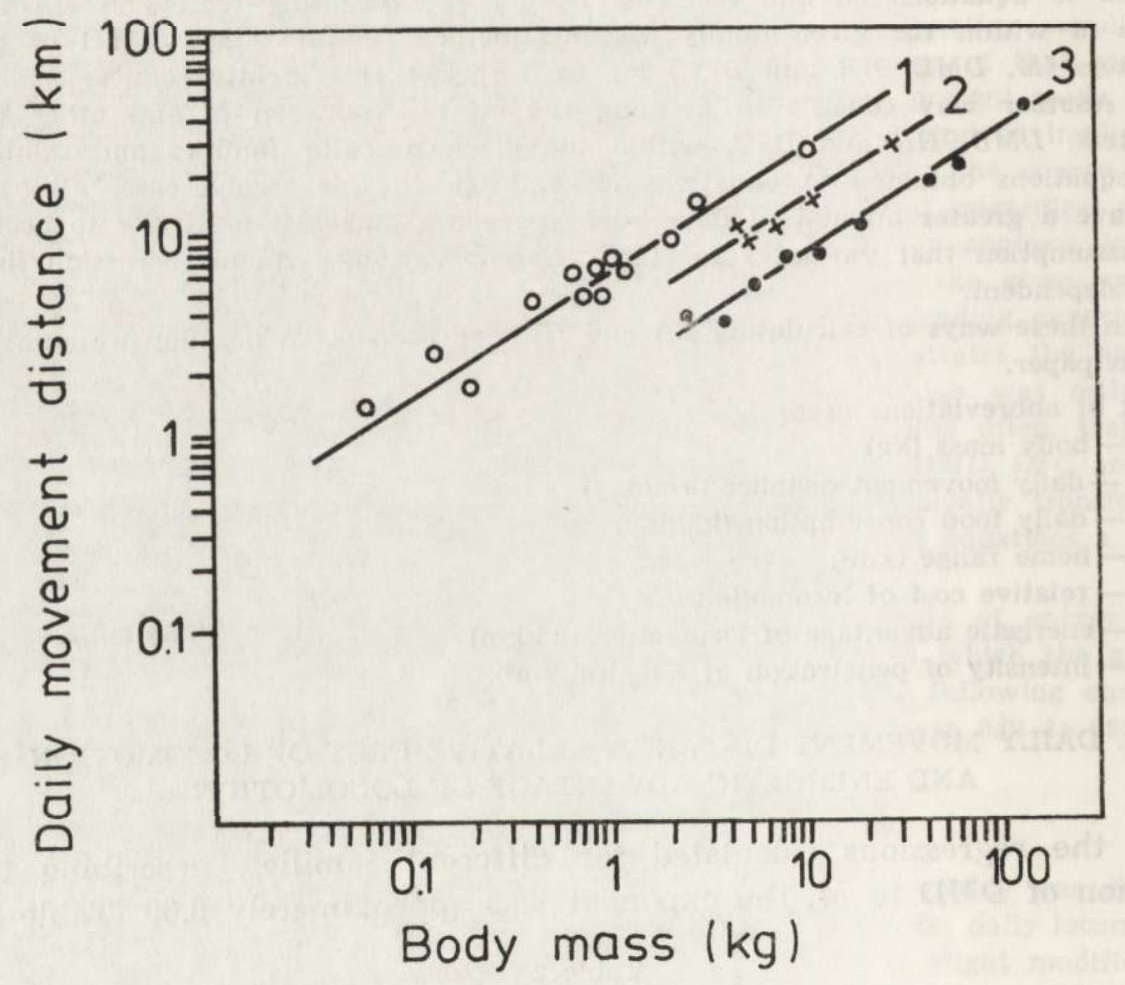

Fig. 1. Relation between body mass $(M)$ and daily movement distance $(D M D)$ for three families of Carnivora. 1 - Mustelidae, 2 - Canidae, 3 - Felidae.

The following equations for $R C L$ were obtained for the three families (Mustelidae - M., Canidae - C., Felidae - F.) on the basis of regression equations from Table 2 and equation (2):

$$
\begin{aligned}
& R C L_{M .}=5.930 M^{0.70} \\
& R C L_{C .}=4.127 \quad M^{0.55} \\
& R C L_{F .}=2.013 M^{0.52}
\end{aligned}
$$


Although the largest representatives of the three families considered differ greatly in respect of body mass (wolverine about $15 \mathrm{~kg}$, wolf about $40 \mathrm{~kg}$ and tiger about $230 \mathrm{~kg}$ ) the costs they have to bear are similar and form about $30-40 \%$ DFC. A similar boundary is thus reached by animals differing in size, representing different intensity of locomotion.

$E A$, that is, advantage expressed by the number of energy units obtained during movement of a distance of one kilometer, is the lowest in the case of Mustelidae, intermediate in Canidae and highest in Felidae (Table 3 ). The equations obtained, regardless of whether they were cal-

Table 3

Least squares regression analyses of $\log _{1 n}$ transformed energetic advantage versus body mass data. Respective values $a$ and $b$ obtained from relating equations from Table 2 to equation (3) are given in brackets.

\begin{tabular}{|c|c|c|c|c|}
\hline \multirow{2}{*}{ Data set } & \multicolumn{4}{|c|}{ Linear regression estimate of $E A=a$ (mass) $^{b}$} \\
\hline & $a$ & $b \pm 95 \%$ C.I. & $r^{2}$ & $n$ \\
\hline Mustelidae & $\begin{array}{c}182.2 \\
(180.0)\end{array}$ & $\begin{array}{l}0.00 \pm 0.19 \\
(0.00)\end{array}$ & 0.00 & 10 \\
\hline Canidae & $\begin{array}{c}231.2 \\
(259.0)\end{array}$ & $\begin{array}{l}0.19 \pm 0.50 \\
(0.15)\end{array}$ & 0.41 & 4 \\
\hline Felidae & $\begin{array}{c}434.1 \\
(526.0)\end{array}$ & $\begin{array}{l}0.22 \pm 0.07^{1} \\
(0.18)\end{array}$ & 0.94 & 7 \\
\hline Canidae + Felidae & 276.3 & $0.29 \pm 0.22^{1}$ & 0.51 & 11 \\
\hline
\end{tabular}

${ }^{1}$ Slope (b) significant at $p<0.05$.

culated on the basis of unprocessed data (from Table 1), are characterized by similar coefficients $a$ and $b$ (Table 3 ). $E A$ in the case of $M u$ stelidae is independent of the animal's size, and in the case of Felidae and Canidae treated jointly, advantage increases with increase in body mass (Table 3).

\section{INTENSITY OF PENETRATION OF THE HOME RANGE BY PREDATORS}

The value of the exponent in relations $H R$ versus $M$ exceeds the value of the exponent of equations for the relation $D M D$ versus $M$ (cf. Table 2), which means that the value of $H R$ increases more rapidly than $D M D$ with increase in body mass. Intensity of penetration of $H R$ thus decreases with increase in the predator's size and this decrease is observed within all the three families considered (Table 4). Canidae penetrate their $H R$ most intensively $(F=27.5, p<0.001)$. 


\section{DISCUSSION}

Mustelidae are characterized by the greatest length of DMD. Over a 24-hour period they cover a far greater distance than Canidae and Felidae with the same body mass. This is in itself astonishing, since representatives of Canidae have so far been considered as typical "runners".

This is probably connected with the hunting methods used by predators belonging to the particular families. Mustelidae actively search over an area, hunting singly for prey which they catch in burrows, nests or sheltering places. This type of hunting necessitates covering con-

Table 4

Least squares regression analyses of $\log _{10}$ transformed intensity of penetration of $\mathrm{HR}$ versus body mass data. Respective values $a$ and $b$ obtained from relating equations from Table 2 to equation (4) are given in brackets.

\begin{tabular}{|c|c|c|c|c|}
\hline \multirow{2}{*}{ Data set } & \multicolumn{3}{|c|}{ Linear regression estimate of $I P=a$ (mass) $^{b}$} & \multirow[b]{2}{*}{$n$} \\
\hline & $a$ & $b \pm 95 \%$ C.I. & $r^{2}$ & \\
\hline Mustelidae & $\begin{array}{c}0.740 \\
(0.614)\end{array}$ & $\begin{array}{l}-1.25 \pm 0.31 \\
(-1.19)\end{array}$ & 0.90 & 11 \\
\hline Canidae & $\begin{array}{c}11.760 \\
(13.065)\end{array}$ & $\begin{array}{l}-1.30 \pm 0.52 \\
(-1.17)\end{array}$ & 0.95 & 5 \\
\hline Felidae & $\begin{array}{c}2.514 \\
(2.090)\end{array}$ & $\begin{array}{l}-0.80 \pm 0.37 \\
(-0.76)\end{array}$ & 0.86 & 6 \\
\hline
\end{tabular}

siderable distances and has low productivity from the energy aspect. Although some representatives of this family use other hunting methods (e.g. Martes flavigula sometimes hunts in groups of several individuals (Hepther \& Naumov, 1967) and Martes pennanti may specialize in catching specific prey (Powell, 1980), these are somewhat exceptional. It may be that their lack of speed, although compensated for by their agility, does not permit of their applying a more varied range of hunting techniques.

Canidae, although also hunting for prey in burrows and nests, in addition makes considerable use of chasing. Felidae, on the other hand. have specialized in hunting by stealth, in hunting by driving their prey to a desired spot, in stalking etc. (Curio, 1976). In the case of Canidae (Bekoff et al., 1981) and also Felidae, the size of the group increases with increase in body mass, thus increasing the possibilities of group hunting which may prove more productive. This probably provides the explanation of increase in energetic advantage of locomotion observed in representatives of these two groups. Specific habitat conditions, making stealthy approach to potential prey possible, and high density of 
prey in $H R$ may also play some part, particularly in the case of large representatives of Felidae leading a solitary way of life.

Analyses of data in literature on DMD shows that some of the most important factors affecting diversity of movement are:

1. Food supply in the given area. The importance of this factor is particularly strongly emphasized by Soviet authors (Heptner \& Naumov, 1967; Nasimovič, 1973; and others) who have shown that length of movements greatly increases with lesser accessibility of prey.

2. Differences in body mass in males and females, particularly distinct among Mustelidae and Felidae. The distance covered by females, which are characterized by lesser body mass, is usually shorter than that of males (cf. Pulliainen, 1980 a).

3 . Weather conditions. For example, reduction in daily distance covered by stoats was observed after snowfall or thaw (Nasimovič, 1977). There are also cases of reduction in DMD during periods of severe frosts (Kraft, 1966).

Analysis of data in literature also shows that $D M D$ varies to a lesser degree than $H R$. Values of the coefficient of variation for $D M D$ and $H R$ (only those papers in which these two parameters were estimated simultaneously have been used for calculations) are for example:

$$
\begin{aligned}
& \text { Mustela erminea C.V. } \cdot_{D M D}=49 \%, C . V \cdot \cdot_{H R}=104 \% \\
& \text { Martes martes C.V.DMD }=31 \%, C . V \cdot \cdot_{H R}=84 \% \\
& \text { Martes zibellina C.V.D.DD }=35 \%, C . V \cdot \cdot_{H R}=88 \% \\
& \text { Gulo gulo C.V.DMD }=17 \%, C . V \cdot \cdot_{H R}=109 \%
\end{aligned}
$$

It would therefore appear that $D M D$ may be widely used for estimating density of predators everywhere where weather conditions make this possible. At the present time this method is not used except in the Soviet Union (e.g. Priklonski, 1965) and Scandinavia (Pulliainen, 1979). Radiotelemetric techniques may, however, be currently employed in order to obtain a very accurate definition of $D M D$ and its variations. This is possible by means of increasing the number of the animal's locations, application of automatic recording or by comparison of successive radiolocations with the route covered by the animals in the field, as Powell (1980) has done.

Analyses of relations between the predator's body mass and home range size shows that the exponent $b$ in the equation $H R=a M^{b}$ is far higner than $b=0.75$ suggested by McNab (1963) and close to $b=1.36$ given in the paper by Harestad \& Bunnell (1979). HR reflects the accessibility of prey to predators in the habitat and would also appear to reflect the effectiveness of the predator's hunting activity. With increase 
in body mass predators change the composition of their food from small to larger prey which, however, is far more scattered, more active and less productive than small prey. The mean values of $H R$ for the same or similar Eurasian and North American species (Harestad \& Bunnell, 1979) are similar (wolf: $231 \mathrm{~km}^{2}$ and $203 \mathrm{~km}^{2}$ respectively; Martes flavigula $-250 \mathrm{~km}^{2}$, Martes pennanti $-203 \mathrm{~km}^{2}$ ). Greater divergences may be caused primarily by differences in accessibility of food which, as shown by Gittleman \& Harvey (1982), may exert a very strong influence on the size of the $H R$ exploited.

Analysis of the way in which hunting grounds are used by predatory mammals shows that larger species penetrate their territory less intensively. Large species thus have lower probability of directly or indirectly recording their presence (by marking with urine, faeces or olfactory substances) and protecting the boundaries of their territory. It is therefore to be expected that in the case of large predators home ranges overlap to a great extent. Data in literature on Mustelidae provide confirmation of this assumption, that small predators, e.g. weasels (Lockie, 1966), stoats (Erlinge, 1977) are more territorial than larger species, e.g. martens (Pulliainen, 1980 a).

The majority of the species within the families under consideration are characterized by small body dimensions, animals exceeding $5 \mathrm{~kg}$ body mass among Mustelidae forming exceptions (Heptner \& Naumov, 1967; Cowan \& Guignet, 1978), $15 \mathrm{~kg}$ among Canidae (Heptner \& Naumov, 1967) and $100 \mathrm{~kg}$ among Felidae (Heptner \& Naumov, 1972). The majority of the species are thus distinguished by locomotion costs below $15-20 \%$ of $D F C$. It must be emphasized that $R C L$ is a measure of the costs borne not only in localizing and obtaining food, and thus typical hunting activity, but also costs borne in marking territory and sometimes in certain forms of sexual activity. The fact deserves mention that large representatives of the above families have similar $R C L$, which may mean that there is an upper limit to worthwhile costs of locomotion.

In view of the relatively low energy losses involved in locomotion by small predators it is probable that they may exhibit considerable variations in $D M D$ in comparison with large species. The C.V. values given above for Mustelidae are actually greater in the case of small animals. On the other hand small Carnivora may experience proportionately greater losses of energy during their movements over snow than large predators. In addition to energy losses connected with locomotion, small predators (chiefly Mustelidae and Canidae) loose a large amount of energy in the actual process of obtaining food. This kind of hunting activity (digging through snow, digging out the nests of rodents, etc. is very 
costly from the energy aspect (Segal et al., 1976) and consequently may reduce their potentially great activity.

Acknowledgements: The author wishes to express his gratitude to Doc. $\mathrm{dr}$ hab. Joanna Gliwicz for her assistance with English terminology, and also to the anonymous reviewers for hteir valued comments on the typescript of this paper.

\section{REFERENCES}

1. Abelencev V. I., 1968: Fauna Ukraini. Naukova dumka, 1: 1-279. Kiev.

2. Abramov V. K. \& Pikunov D. G., 1976: Redkije vidy hiščnyh zverej juga Dalnevo Vostoka SSSR. [In: "Redkije mlekopitajuščije fauny SSSR", Ed. Sokolov V. E.]. Izd. Nauka: 67-96. Moskva.

3. Andersson M. \& Erlinge S., 1977: Influence of predation on rodent populations. Oikos, 29: 591-597.

4. Bajsfeld M. A., 1972: Ekologia gornostaja $\mathrm{v}$ holodnyj period goda na Evropejskom Severe. Zool. Ž., 61: 1705-1713.

5. Banfield A. W. F., 1954: Preliminary investigation of the barren ground caribou. Part II. Life history, ecology, and utilization. Can. Wildlife Serv., Wildl. Manage. Bull., ser. 10 B: $1-112$.

6. Bekoff M., Diamond J. \& Mitton .I. B., 1981: Life history patterns and sociality in canids: Body size, reproduction, and behavior. Oecologia, 50: 386 -390 .

7. Berrie P. M., 1973: Ecology and status of the lynx in interior Alaska. [In: "The World's cats. I. Ecology and conservation", Ed. R. L. Eaton]. World Wildlife Safari and Institute for the Study and Conservation of Endangered Species, 281-301. Winston, Oregon, USA.

8. Bertram B. C. R., 1976: Kin selectin in lions and its evolution. [In: "Growing points in ethology", Eds. P. P. G. Bateson \& Hinde R. A.]. Cambridge University Press: 281-301. Cambridge.

9. Benkovskij L., 1972: Kolonok na Sahaline. Ohota i ohotničje hozjajstvo, 8: $20-21$.

10. Birks J. D. S. \& Linn I. J., 1982: Studies of home range of the feral mink, Mustela vison. Symp. zool. Soc. Lond., 49: 231-257.

11. Bowen W. D., 1982: Home range and spatial organization of coyotes in Jasper National Park, Alberta. J. Wildl. Manage., 46: 201-216.

12. Brand Ch. J., Keith L. B. \& Fischer Ch. A., 1976: Lynx responses to changing snowshoe hare densities in Central Alberta. J. Wildl. Manage., 40: $416-428$.

13. Brown H. J. \& Lasiewski R. C., 1972: Metabolism of weasels: the cost of being long and thin. Ecology, 53: 939-943.

14. Bruce J., 1925: The problem of mountain lion control in California. California Fish and Game, 11: 1-17.

15. Burkholder B. L., 1959: Movements and behavior of a wolf pack in Alaska. J. Wildl. Manage., 23: 1-11.

16. Burt W. H. \& Grossenheider R. P., 1976: A field guide to the mammals. 3d ed. Houghton-Mifflin. New York.

17. Chanin P. R. F., 1972: The ecology of feral mink (Mustela vison Schreber) in Devon. Unpublished Ph. D. thesis. University of Exeter. 
18. Cowan I. McT., 1947: The timber wolf in the Rocky Mountain National Parks of Canada. Can. J. Res. Sect. D, 25: 139-174.

19. Cowan I. McT. \& Guignet C. J., 1978: The mammals of British Columbia. British Columbia Museum: 1-414. Victoria.

20. Curio E., 1976: The ethology of predation. Springer-Verlag: 1-250. Berlin, Heidelberg, New York.

21. Danilov P. I. \& Rusakov O. S., 1969: Osobiennosti ekologii cernovo horia (Mustela putorius) v severo-zapadnyh oblastiah evropejskoj časti SSSR. Zool. Ž., 68: $1383-1395$.

22. Danilov P. I., Rusakov O. S. \& Tumanov I. L., 1979: Hiščnyje zverii severo-zapada SSSR. Izd. Nauka: 1-163. Leningrad.

23. DeVos A., 1951: Recent findings in fisher and marten ecology and management. Trans. North Am. Wildl. Conf., 16: 498-507.

24. Erlinge S., 1974: Distribution, territoriality and numbers of the weasels $M u$ stela nivalis in relation to prey abundance. Oikos, 25: 308-314.

25. Erlinge S., 1977: Spacing strategy in stoat Mustela erminea. Oikos, 28: 32-42.

26. Erlinge S. \& Jensen B., 1981: The diet of otters Lutra lutra L. in Denmark. Natura Jutlandica, 19: 161-165.

27. Fitch H. S., 1948: A study of coyote relationships on cattle range. J. Wildl. Manage., 12: 73-78.

28. Francis G. R. \& Stephenson A. B., 1972: Marten ranges and food habits in Algonquin Provincial Park, Ontario. Ontario Ministry of Natural Resources, Fish and Wildl. Res. Repport on Wildlife, 91: 1-53.

29. Frankiewicz E., 1962: Lis. Monografia przyrodniczo-łowiecka. Państwowe Wydawnictwa Rolnicze i Leśne: 1-71. Warszawa.

30. Garland Z. Jr., 1983: Scaling the ecological cost of transport to body mass in terrestrial mammals. Am. Nat., 121: 571-587.

31. Gerell R., 1970: Home ranges and movement of the mink (Mustela vison Schreber) in southern Sweden. Oikos, 20: 451-460.

32. Gittleman J. L. \& Harvey P. M., 1982: Carnivore home range size, metabolic need and ecology. Behav. ecol. and Sociobiol., 10: 57-63.

33. Golley F. B., Petrides G. A., Rauber E. L. \& .Jenkins I. H., 1965: Food intake and assimilation by bobcats under laboratory conditions. J. Wildl. Manage., 29: 442-447.

34. Grakov N. N., 1981: Lesnaja kunica. Nauka: 1-109. Moskva.

35. Grinnell J., Dixon .T. S. \& Linsdale .J. M., 1937: Fur-bearing mammals of California. Univ. Calif. Press, 2: 290-625. Berkeley.

36. Haber A. \& Matuszewski G., 1968: The lynx population in Poland. Acta Sc. Nat. Brno, 2: 5-6: 53-56.

37. Haglund B., 1966: De stora rovdjurens vintervanor. Viltrevy, 4: 1-299.

38. Hall H. T., 1973: An ecological study of the bobcats in southern Louisiana. Louisiana Cooperative Wildlife Research Unit Quarterly Report, 14: 7.

39. Harestad A. S. \& Bunnell F. L., 1979: Home range and body weight - a reevaluation. Ecology, 60: 389-402.

40. Haroldson K. J. \& Fretzell E. K., 1984: Home ranges, activity, and habitat use by gray foxes in an oak-hickory forest. J. Wildl. Manage., 48: 222-227.

41. Hawley V. D. \& Newby F. E., 1957: Marten home ranges and population fluctuations. J. Mammal., 38: 174-184.

42. Heptner V. G. \& Naumov N. P., (eds.) 1967: Mlekopitajuščije Sovetskovo Sojuza. II. Morskije korovy i hiščnyje. Vyzšaja Škola: 1-1004. Moskva. 
43. Heptner V. G. \& Naumov N. P., (eds.) 1972: Mlekopitajuščije Sovetskovo Sojuza. II. Hiščnyje (gieny i koški). Vyzšaja Škola: 1-551. Moskva.

44. Hersteinsson P. \& Macdonald D. W., 1982: Red and arctic foxes. Sym. zool. Soc. Lond., 49: 259-289.

45. Jenkins D., 1980: Ecology of otters in Northern Scotland. I. Otter (Lutra lutra) breeding and dispersion in Mid-Deeside, Aberdeenshire in 1974-79. J. Anim. Ecol., 49: 713-735.

46. King C. M., 1975: The home range of the weasel (Mustela nivalis) in an English woodland. J. Anim. Ecol., 44: 639-668.

47. Kolenosky G. B., 1972: Wolf predation on wintering deer in east-central Ontario. J. Wildl. Manage., 36: 357-369.

48. Kolenosky G. B. \& Johnston D. H., 1967: Radio-tracking timber wolves in Ontario. Am. Zool., 7: 289-303.

49. Kopein K. J., 1967: Morfo-fizjologičeskije osobennosti severnyh populacej gornostaja. [In: "Ekologičeskije osnovy adaptacji životnyh", Ed. Švarc S.S.]. Izd. Nauka: 40-49. Moskva.

50. Korčmar N. D., 1969: Lesnaja kunica v Moldavii. Voprosy ekol. i prakt. značenija ptic i mlekopitajuščih Moldavii, 3: 80-86.

51. Kowalski K. (Ed.), 1973: Mały słownik zoologiczny. Ssaki. Wiedza Powszechna: $1-470$. Warszawa.

52. Kraft V. A., 1966: Vlijanie tiemperatury na podvižnost gornostaja zimoj. Zool. Ž., 45: $567-570$.

53. Kratochvíl .J., 1968: Changes in the distribution of the lynx and its protection in Cechoslovakia. Acta Sc. Nat. Brno, 2: 5-6: 4-16.

54. Krott P., R., 1959: Der Vielfrass. Monographien der Wildsäugetiere, 13. Göttingen.

55. Kuris N. M., 1982: Osobennosti vozrastnoj, polovoj i sezonnoj izmenčivosti nekotoryh morfologičeskih priznakov u kolonka. [In: "Voprosy teriologii", Ed. Sokolov V. E.]. Izd. Nauka: 149-166. Moskva.

56. Liberg O., 1980: Spacing patterns in a population of rural free roaming domestic cats. Oikos, 35: $336-349$.

57. Lindström E., 1982: Population ecology of the red fox (Vulpes vulpes L.) in relation to food supply. Dr. Phil. Thesis: $1-24$. Stockholm.

58. Lobačev J. C., 1973: Ekologia kamiennoj kunicy na jugo-vostoke Kazahstana. Trudy Inst. Zool., 34: 107-134.

59. Lockie J. D., 1966: Territory in small carnivores. Symp. zool. Soc. Lond., 18: $143-165$.

60. Lnngstaff T. G., 1932: An ecological reconnaisance in west Greenland. J. Anim. E :ol., 1: 119-142.

61. L.und H. M. K., 1959: The red fox in Norwey I. Survey of 551 red fox collected, their size and sex ratio. Pap. Nor. St. Game Res., 5: 1-57.

62. Marshall W. H., 1951: Pine marten as a forest product. .J. Forestry, 49: $899-905$.

63. Matjuskin E. N., 1979: Rysi Golarktiki. Sb. Tr. Zool. Muz. MGU, 18: 76-162.

64. McNab B. K., 1963: Bioenergetics and the determination of home range size. Am. Natur., 97: 133-140.

65. Mech L. D., 1966: The wolves of Isle Royal. U.S. National Park Service, Fauna of the National Parks of the United States, Fauna ser., 7: 1-210.

66. Mech L. Do, 1970: The wolf: the ecology and behavior of an endangered species. Natural History Press: 1-384. Garden City, N. Y. 
67. Mech L. D., 1973: Wolf numbers in the Superior National Forest in Minnesota. USDA For. Serv. Res. Pap. NC, 97: 1-10.

68. Mech L. D. \& Rogers L. L., 1977: Status, distribution, and movements of martens in northeastern Minnesota. USDA For. Serv. Res. Pap. NC, 143: $1-7$.

69. Miller R. 'G., Ritcey R. W. \& Edwards R. Y., 1955: Live trapping marten in British Columbia. Murrelet, 36: 1-8.

70. Moors P. A., 1974: The annual energy budget of a weasel (Mustela nivalis L.) population in farmland. Unpublished Phil. Dr. Thesis. University of Aberdcen.

71. Myrberget S., Groven B. \& Muhre R., 1969: Jervensporinger i Jotunheimen. Fauna (Norge), 22: 237-252.

72. Nasimovič A. A., 1949: Biologia laski na Kolskom polustrovie $\mathrm{v}$ svjazi z konkurentnymi otnošeniami z gornostajem. Zool. Ž., 28: 177-182.

73. Nasimovič A. A. (Ed.), 1973: Sobol, kunicy, harza. Izd. Nauka: 1-239. Moskva.

74. Nasimovič A. A. (Ed.), 1977: Kolonok, gornostaj, vydra. Izd. Nauka: 1-216. Moskva.

75. Nellis C. H., Wetmore S. P. \& Keith L. B., 1972: Lynx-prey interactions in central Alberta. J. Wildl. Manage., 36: 320-329.

76. Nikitenko M. F. \& Kozlo P. G., 1956: Ekologo-morfologičeskaja harakteristika rysi obitajuščej v Belovežskoj Pušce. [In „Ekologia pozvonočnyh životnyh Bielorussii", eds Rokickij P. P. \& Seržanin I. N.]: 56-64. Minsk.

77. Nyholm E. S., 1959: On stoat and weasel and their winter habitats, Suomen Riista, 13: 106-116.

78. Nyholm E. S., 1970: Näädän elintavoista, saalistuksesta ja ravinnosta. Suomen Riista, 22: 105-118.

79. Ozoga J. J. \& Harger E. M., 1966: Winter activities and feeding habits of northern Michigan coyotes. J. Wildl. Manage., 30: 809-818.

80. Pelikán J., Gaisler J. \& Rodl P., 1979: Nasi šavci. Ces. Akad. VĚD: 1-163. Praha.

81. Peterson R. O., 1977: Wolf ecology and prey relation on Isle Royale. US. Nat. Park Serv. Sci. Monogr., 11: 1-210.

82. Pimlott D. H., Shanon J. A. \& Kolenosky G. B., 1969: The ecology of the timber wolf in Algonquin Provincial Park. Ontario Department of Lands and Forest Research Report on Wildlife, 87: 1-92.

83. Plešak T. V., 1975: K ekologii laski v zimnyj period 1972/73 g. Voprosy biol. promyslov. životnyh i organiz. Ohotn. hozjajstva: $80-83$.

84. Pokrovskij V. S., 1976: Snežnyj bars (irbis). [In: "Redkije mlekopitajuščije SSSR. Krupnyje hiš̌̌niki”, Eds. Syškin J. B., Sludskij A. A. \& Pokrovskij V. S.]. Izd. Lesnaja promyšlennost: 82-98. Moskva.

85. Pollack E. M., 1949: Observation on New England bobcats. J. Mammal., 32: $356-358$.

86. Powell R. A., 1980: Hunting behavior and food requirements of the fisher (Martes pennanti). [In: "Worldwide Furbearer Conference Proceedings". August 3-11, 1980. Frostburg, Maryland USA Eds. Chapman J. A. \& Pursley D.]: 883-917. Frostburg.

87. Prevost E. E.. Nelson C. A. \& Marshall A. D., 1973: Population dynamics. and behavior in the bobcat. [In: "The world's cat. I. Ecology and conservation", Ed. Eaton R. L.]. World Safari and Institute for the Study and Conservation of Endangered Species: 42-67. Winston, Oregon, USA. 
88. Priklonski S. G., 1965: Peresečetnyje koeficienty dla obrabotki dannyh zimnevo maršrutnovo učeta promyslovyh zverej po sledam. Biull. Mosk. Obšč. Izp. Prir., odl. biol., 70: 6: 5-12.

89. Pucek Z. (Ed.), 1981: Keys to vertebrates of Poland. Mammals. Polish Sci. Publ.: 1-367. Warszawa.

90. Pulliainen E., 1979: Erfarenheter av uppföljning av de stora rovdjuren, Finland. Viltrapport, 9: $60-70$.

91. Pulliainen E., 1980 a: Winter habitat selection, home range and movement of the pine marten (Martes martes) in a Finnish Lapland Forest. [In: "Worldwide Furbearer Conference Proceedings". August 3-11, 1980, Frostburg, Maryland USA, Eds. Chapman J. A. \& Pursley D.]: 1068-1087. Frostburg.

92. Pulliainen E., 1980 b: Food and feeding habits of pine marten in Finnish Lapland forest in winter. [In: "Worldwide Furbearer Conference Proceedings". August 3-11, 1980, Frostburg, Maryland USA, Ed. Chapman J. A. \& Pursley D.]: 580-598. Frostburg.

93. Pulliainen E., Iivanainen J., Laitinen M. \& Vaarala K., 1980: Suden elämää porojen keskella. Suomen Luonto, 3: 118-119.

94. Quick H. F., 1944: Habits and economies of the New York weasel in Michigan. J. Wildl. Manage., 32: 71-78.

95. Quick H. F., 1951: Notes on the ecology of weasels in Gunnison County, Colorado. J. Mammal., 32: 281-290.

96. Quick H. F., 1953: Volverine, fisher, and marten studies in a wilderness region. Trans. North Am. Wildl. Conf., 18: 513-533.

97. Robinette W. J., Gashwiler J. S. \& Morris O. W., 1959: Food habits of the cougar in Utah and Nevada. J. Wildl. Manage., 23: 261-273.

98. Robinson D., 1976: Puma! Puma! Defenders, 51: 97-104.

99. Rollings C. T., 1945: Habits, food and parasites of the bobcats in Minnesota. J. Wildl. Manage., 9: 131-145.

100. Ryszkowski L., 1982: Structure and function of the mammal community in an agricultural landscape. Acta zool. Fennica, 169: 45-59.

101. Ryszkowski L., Goszczyński J. \& Truszkowski J., 1973: Trophic relationships of the common vole in cultivated fields. Acta theriol., 18: 125-165.

102. Saunders J. K. Jr., 1963: Movements and activities of the lynx in Newfoundland J. Wildl. Manage., 27: 390-400.

103. Schaler G. B., 1972: The Serengeti lion. Chicago University Press: $1-480$ Chicago.

104. Schantz T. von, 1980: Prey consumption of the red fox population in southern Sweden. Biogeographica, 18: $53-64$.

105. Schoener T. W. 1968: Sizes of feeding territories among birds. Ecology, 49: 123-141.

106. Scott T. E., 1943: Some food coactions of northern plains red fox. Ecol. Monogr., 13: $427-479$.

107. Segal A. N., 1978: Metabolizm i termoregulacja u lesnevo horka (Putorius putorius). Zool. Ž., 57: 1412-1416.

108. Segal A. N., Popovi夭 T. A. \& Vain-Rib M. A., 1976: Nekotoryje ekologo-fizjologið̌skije harakteristiki pesca (Alopex lagopus). Zool. Z., 55: 741-744

109. Seidensticker J. C., Hornocker M. G., Wiles M. V. \& Messick .T. P., 1973: Mountain lion social organization in the Idaho Primitive Area. Wildl. Monogr., 35: $1-60$.

110. Sludskij A. A., 1976: Leopard. [In: "Redkije mlekopitajušrije SSSR, Krupnyje 
chiščniki", Eds. Syskin J. B., Sludskij A. A. \& Pokrovskij V. S.]. Izd. Lesnaja promyšlennost: 58-82. Moskva.

111. Soest van R. W. M. \& Bree van P. J. H., 1970: Sex and age composition of a stoat population (Mustela erminea Linnaeus, 1758) from a coastal dune region of the Netherlands. Beaufortia, 226: $51-77$.

112. Sokolov V. E. \& Rožnov V. V., 1979: Teritorialnost, agresivnost i markirovka u kunic (Mustelidae). Sb. Trud. zool. Muz. MGU, 18: 163-214.

113. Speller S. W., 1972: Food ecology and hunting behavior of dening arctic foxes at Aberdeen Lake, Northwest Territories. Unpublished Dr. Phill. Thesis. University of Saskatchewan.

114. Springer J. T., 1982: Movement patterns of coyotes in south-central Washington. J. Wildl. Manage., 46: 191-200.

115. Stebler A. M., 1944: The status of the wolf in Michigan. J. Mammal., 25: $37-43$.

116. Stenglund M. H., 1955: A field study of the timber wolf (Canis lupus) in the Superior National Forest, Minnesota. Minnesota Department of Conservation, Tech. Bull., 4: $1-55$.

117. Steventon I. D. \& Major J. T., 1982: Marten use of habitat in a comercially clear-cut forest. J. Wildl. Manage., 46: 175-182.

118. Sysojev N. D., 1966: Rys i stepnoj horek vo Vladymirskoj oblasti. Zool. Ž., 45: $1269-1270$.

119. Syškin I, B., 1976: Tigr. [In: "Redkije životnyje SSSR. Krupnyje hiščniki", Eds. Syškin I. B., Sludskij A. A. \& Pokrovskij V. C.]. Izd. Lesnaja promyšlennost: 10-58. Moskva.

120. Taylor C. R., 1980 a: Energetics of locomotion: primitive and advanced mammals. [In: "Comparative physiology: primitive mammals", Eds. Schmidt. Nielsen K., Bolis L. \& Taylor C. R.]. Cambridge University Press: 199-199. Carnbridge,

121. Taylor C. R., 1980 b: Mechanical efficiency of terrestrial locomotion: a useful concept? [In: "Aspects of animal movement", Eds. Elder H. Y. \& Trueman E. R.]. Cambridge University Press: $235-244$. Cambridge.

122. Ternovskij D. V., 1977: Biologia kuniceobraznyh. Izd. Nauka: 1-280. Novosibirsk.

123. Thompson D. Q., 1952: Travel, range, and food habits of timber wolves in Wisconsin. J. Mammal., 33: 429-442.

124. Wassmer D. P., 1984: Movements and activity patterns of a gray fox in south-central Florida. Fla. Sci., 47: 76-77.

125. Weachter A., 1975: Ecologie de la fouine en Alsace. Terre et la Vie, 24: 399-457.

126. Zivotčenko V. J., 1977: Zasielenie tigrom (Panthera tigris altaica) teritorii Lazavskovo zapovednika i evo vzaimootnošenija z leopardom i volkom. Zool. Ž., 56: $130-140$.

127. Young S. P. \& Goldman E. A., 1964: The puma, mysterious American cat. Dover, New York.

Accepted, September 5, 1985. 
Jacek GOSZCZYÑSKI

\section{LOKOMOTORYCZNA AKTYWNOSC LĄDOWYCH DRAPIEŻNYCH I JEJ KONSEKWENCJE}

Streszczenie

Analizowano zależności między masą ciała zwierzęcia $(M)$ a: długością dobowej wędrówki ( $D M D)$, wielkością areału $(H R)$ i dobową konsumpcją pokarmu (DFC) w obrębie trzech rodzin z rzędu Carnivora (Tabela 1). Analiza dotyczyła gatunków euroazjatyckich i północnoamerykańskich.

Stwierdzono, że lasicowate w c'ągu doby przemieszczają się na większe odległości niż psowate i kotowate o tej samej masie ciała (Tabela 2 i Ryc. 1).

Względne koszty lokomocji zwierzęcia wyliczono wg wzoru:

$$
R C L(\%)=\frac{D M D 10,678 M^{0.70}}{D F C} \times 100
$$

Koszty te wzrastają ze wzrostem masy ciała zwierzęcia. Potwierdza to wcześniejsze ustalenia Garlanda (1983). W przypadku największych przedstawicieli analizowanych rodzin koszty lokomocji stanowią $30-40 \%$ ich DFC.

Zyski energetyczne zwierzęcia ( $E A)$ mierzone stosunkiem $D F C$ do $D M D$ są w przypadku Mustelidae niezależne od masy ciała, natomiast Felidae i Canidae zwiększają zysk ze wzrostem masy ciała (Tabela 3 ).

Intensywność penetracji (IP) własnego areału (stosunek $D M D$ do $H R$ ) spada ze wzrostem wielkości drapieżnika (Tabela 4). Wśród analizowanych rodzin najsilniej penetrują swój areał psowate (Tabela 4).

Wykazano, że DMD jest mniej zmienna niż HR. Omówiono konsekwencje zróż. nicowania $R C L$ i $I P$ w przypadku dużych i małych drapieżnych. 